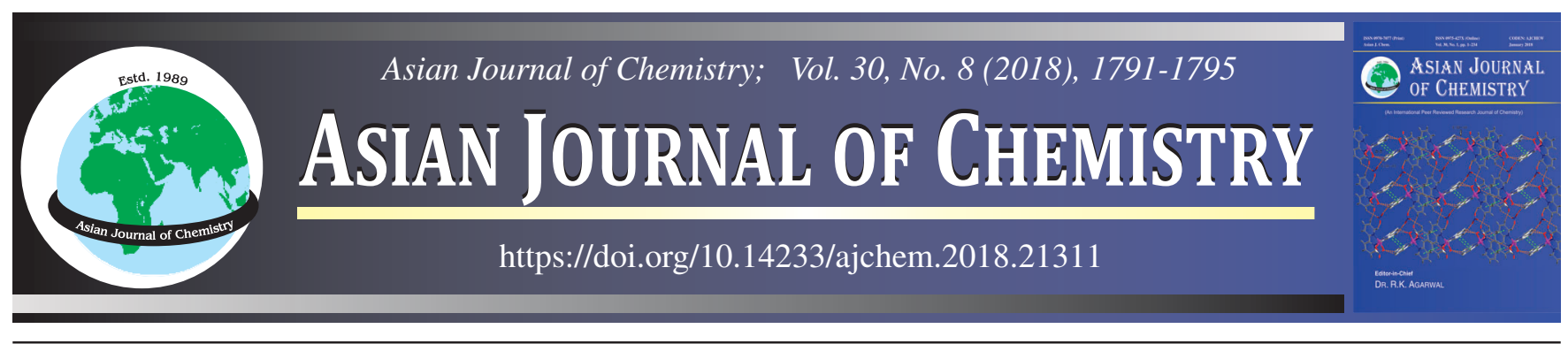

\title{
GC-HS Method for Organic Volatile Impurities Determination and Quantification in Sertraline HCl API and Its Pharmaceutical Dosage Forms
}

Mannem Durga Babu* and Kesana Surendra Babu

Department of Chemistry, ANU Research Centre, Shree Velagapudi Ramakrishna Memorial P.G. College, Nagaram-522268, India

*Corresponding author: E-mail: m.durgababu1989@gmail.com

Received: 1 March 2018;

Accepted: 3 May 2018;

Published online: 30 June 2018;

AJC-18976

\begin{abstract}
In this work, a simple and sensitive GC-HS method for simultaneous determination of organic volatile impurities (methanol and ethyl acetate) in sertraline $\mathrm{HCl}$ API and its pharmaceutical dosage forms by GC-HS with FID. Based on good manufacturing practices, measuring organic volatile impurities are mandatory for the testing of all API's. In order to remove the potential toxic risk of residual solvents, an efficient and sensitive GC-HS method was successfully developed and validated. The method involved a thermal gradient elution of | organic volatile impurities present in sertraline $\mathrm{HCl}$ API. DB-624, $30 \mathrm{~m} \times 0.53 \mathrm{~mm} \times 3.0 \mu \mathrm{m}$ column using nitrogen as a carrier gas. The flow rate was $3 \mathrm{~mL} / \mathrm{min}$ and FID was used. And the detector temperature is $250{ }^{\circ} \mathrm{C}$ and injector temperature is $225^{\circ} \mathrm{C}$. The total run time is $25 \mathrm{~min}$. This method was validated for repeatability, method precession, linearity, limit of detection, limit of quantification, tablet analysis, solution stability and accuracy according to ICH guidelines.
\end{abstract}

Keywords: GC-HS method, Sertraline HCl, Methanol, Ethyl acetate.

\section{INTRODUCTION}

Sertraline $\mathrm{HCl}$ (Fig. 1) is a selective serotonin reuptake inhibitor for oral administration. The chemical name is $(1 \mathrm{~S}, 4 \mathrm{~S})$ 4-(3,4-dichlorophenyl)- $N$-methyl-1,2,3,4-tetrahydronaphthalen-1-amine hydrochloride. Sertraline $\mathrm{HCl}$ is white crystalline powder and slightly soluble in water and isopropyl alcohol and sparingly soluble in ethanol [1].<smiles>CN[C@H]1CC[C@@H](c2ccc(Cl)c(Cl)c2)c2ccccc21</smiles>

Fig. 1. Sertraline hydrochloride (m.f. $\mathrm{C}_{17} \mathrm{H}_{18} \mathrm{NCl}_{3}$; m.w. 342.69)

The organic volatile impurities (OVI's) specifications were set in accordance with the toxicity of solvents vary from a low ppm to thousands of ppm. The static GC-HS deamination of OVI's is now a days mature technique well established in pharmaceutical analysis [2-4]. The OVI's are used in produced during the synthesis of drug substances and in excipients used in the production of drug formulations. Many of these OVI's generally cannot be completely removed by standard manufacturing processes preferably at low levels. These organic volatile impurities are encounter during manufacture and storage of active pharmaceutical ingredients. The OVI's in active pharmaceutical ingredients or from other drug manufacturing processes can be harmful for the human health [5-7].

This method for the simultaneously determination and quantification of two organic volatile impurities (ethyl acetate and methanol) in sertraline $\mathrm{HCl}$ by gas chromatography with headspace sampler fitted with flame ionization detector was proposed. This method is very simple, accurate and precise.

\section{EXPERIMENTAL}

Sertraline $\mathrm{HCl}$ was procured from local well-known laboratory in Hyderabad, India. HPLC grade acetonitrile (E. Merck, India), HPLC grade methanol (E. Merck. India). Milli-Q water, ethyl acetate and methanol manufactured by Merck were used.

The total analysis was performed on Shimadzu GC-2010 system with FID. Samples were injected through a Teledyne tekmar HT3TM Head space. The chromatographic data acquisition and integration was performed used by GC-solution software.

Chromatographic conditions: The column is DB-624 $(30 \mathrm{~m} \times 0.53 \mathrm{~mm} \times 3 \mu \mathrm{m})(6 \%$ cyanopropylphenyl-94\% dimethyl 
polysiloxane) and the carrier gas is nitrogen. The total flow rate is $3.0 \mathrm{~mL} / \mathrm{min}$ and injector temperature is $225^{\circ} \mathrm{C}$. The split ratio was $1: 20$. Oven program is initial temperature is $40{ }^{\circ} \mathrm{C}$ hold for $5 \mathrm{~min}$ than increase $20^{\circ} \mathrm{C} / \mathrm{min}$ up to $200^{\circ} \mathrm{C}$ than hold for $12 \mathrm{~min}$. Detector temperature is $250{ }^{\circ} \mathrm{C}$, air flow is 400 $\mathrm{mL} / \mathrm{min}$ and hydrogen flow is $40 \mathrm{~mL} / \mathrm{min}$. The total run time is $25 \mathrm{~min}$.

Headspace sampler condition: Vial temperature: $80^{\circ} \mathrm{C}$; needle temperature: $100^{\circ} \mathrm{C}$; transfer line temperature: $110^{\circ} \mathrm{C}$; vial conditioning time: $30 \mathrm{~min}$; vial pressurize time: $3.0 \mathrm{~min}$; inject time: $1.0 \mathrm{~min}$; GC cycle time: $45 \mathrm{~min}$.

Dimethyl sulfoxide used as diluent.

Blank preparation: Take $2 \mathrm{~mL}$ of dimethyl sulfoxide in a headspace vial and seal with aluminum septum and crimp the cap.

Standard solution preparation: Weighed and dissolved accurately $12.5 \mathrm{mg}$ of methanol and $25 \mathrm{mg}$ of ethyl acetate in $70 \mathrm{~mL}$ of diluent taken in a $100 \mathrm{~mL}$ volumetric flask. Finally make up to the mark with diluent (The final concentration of methanol is $500 \mathrm{ppm}$ and ethyl acetate is $1000 \mathrm{ppm}$ with respect to test solution).

Preparation of standard vial: Take $2 \mathrm{~mL}$ of standard stock solution in a headspace vial and seal seal with aluminum septum and crimp the cap.

Sample preparation: Accurately weighed and transferred about $500 \mathrm{mg}$ of sertraline $\mathrm{HCl}$ API into a headspace vial. Then, added $2 \mathrm{~mL}$ of diluent and immediately sealed with aluminum septum and crimp the cap.

Tablet preparation: Twenty tablets were weighed and powdered. Accurately weighed and transferred an amount of powder equivalent to $500 \mathrm{mg}$ of sertraline $\mathrm{HCl}$ to $2 \mathrm{~mL}$ head space vial then add $2 \mathrm{~mL}$ of diluent and immediately sealed with aluminum septum and crimp the cap. The mixture was sonicated for $5 \mathrm{~min}$.

The organic volatile impurity content (ppm) was calculated by using the following formula:

$$
\begin{aligned}
\text { Calculation }(\mathrm{ppm})= & \frac{\text { Impurity area in test solution }}{\text { Impurity area in standard solution }} \times \\
& \frac{\text { Standard concentration }(\mathrm{mg})}{\text { Sample concentration }(\mathrm{mg})} \times 10^{6}
\end{aligned}
$$

\section{RESULTS AND DISCUSSION}

Method development: This method development was implemented following quality-by-design principles including diluent selection, column selection.

Diluent selection: Different diluents (DMF, NMP and DMSO) was experimentally tried for selection. Dimethyl sulfoxide was preferred over other diluents since, methanol, ethyl acetate and sertraline $\mathrm{HCl}$ are easily dissolved in DMSO.

Column selection: In this study, three columns are used namely, VF-1(30 m $\times 0.32 \mathrm{~mm} \times 0.45 \mu \mathrm{m})$, DB-624 (30 m $\times$ $0.53 \mathrm{~mm} \times 3.0 \mu \mathrm{m})$ and DB-624 $(30 \mathrm{~m} \times 0.25 \mathrm{~mm} \times 0.25 \mu \mathrm{m})$ for evaluated for column screening. The GC-HS parameters were first optimized to achieve good retention time, acceptable resolution and better peak shapes for methanol and ethyl acetate in sertraline $\mathrm{HCl}$ and its formulations. The DB-624 eluted three sharp peaks with minimal peak tailing for methanol at retention time about $3.726 \mathrm{~min}$ and ethyl actate at about $8.33 \mathrm{~min}$. It demonstrated that DB-624 column closely matched methanol and ethyl acetate. Hence, DB-624 column was selected for this study.

Method validation: The GC-HS method was validated as per ICH guidelines [8]. The validation parameters viz., specificity, repeatability, method precision, limit of detection (LOD) and limit of quantitation (LOQ), linearity, accuracy, ruggedness and robustness were evaluated.

Specificity: This specificity was determined to confirm the analyte identity from other interferences. Specificity has been established by injections of methanol and ethyl acetate individually. The resolution obtained between the peaks was not less than 5.0. No peaks were observed in blank injection. A typical chromatograms and retention times are shown in Fig. 2 and Table-1, respectively.

TABLE-1

SPECIFICITY DATA FOR METHANOL AND ETHYL ACETATE

\begin{tabular}{lccccc}
\hline Name & $\begin{array}{c}\text { Reten- } \\
\text { tion } \\
\text { time }\end{array}$ & Area & $\begin{array}{c}\text { USP } \\
\text { resolution }\end{array}$ & $\begin{array}{c}\text { USP } \\
\text { plate } \\
\text { count }\end{array}$ & $\begin{array}{c}\text { USP } \\
\text { tailing }\end{array}$ \\
\hline Methanol & 3.726 & 161010 & 0.00 & 30225 & 1.49 \\
Ethyl acetate & 8.330 & 1013141 & 46.04 & 84248 & 1.11 \\
\hline
\end{tabular}

System and method precision: The system precision of proposed method was expressed in the terms of \% RSD of data. System precision has been demonstrated by six replicates injection of standard solutions. The RSD was found out to be less than $10 \%$ (Table-2). While the method precision has been demonstrated by separately analyzing of sample six preparations. RSD was found to be less than $10 \%$ (Table-3).

\begin{tabular}{ccc|cc}
\multicolumn{4}{c}{ TABLE-2 } \\
\multicolumn{4}{c}{ SYSTEM PRECISION DATA FOR } \\
METHANOL AND ETHYL ACETATE \\
\hline SST & \multicolumn{2}{c}{ Methanol } & \multicolumn{2}{c}{ Ethyl acetate } \\
\cline { 2 - 5 } parameters & RT $(\mathrm{n}=6)$ & Area $(\mathrm{n}=6)$ & $\mathrm{RT}(\mathrm{n}=6)$ & Area $(\mathrm{n}=6)$ \\
\hline Mean & 3.70 & 142539 & 8.30 & 960498 \\
STDV & 0.00 & 4128 & 0.001 & 22666 \\
RSD $(\%)$ & 0.01 & 2.90 & 0.01 & 2.36 \\
\hline
\end{tabular}

\begin{tabular}{ccc|cc}
\multicolumn{5}{c}{ TABLE-3 } \\
\multicolumn{5}{c}{$\begin{array}{c}\text { METHOD PRECISION DATA FOR } \\
\text { METHANOL AND ETHYL ACETATE }\end{array}$} \\
\hline SST & \multicolumn{2}{c}{ Methanol } & \multicolumn{2}{c}{ Ethyl acetate } \\
\cline { 2 - 5 } parameters & RT $(\mathrm{n}=6)$ & Area $(\mathrm{n}=6)$ & RT $(\mathrm{n}=6)$ & Area $(\mathrm{n}=6)$ \\
\hline Mean & 3.71 & 105402 & 8.31 & 892873 \\
STDV & 0.00 & 3600 & 0.001 & 30835 \\
RSD $(\%)$ & 0.01 & 3.42 & 0.01 & 3.45 \\
\hline
\end{tabular}

Linearity (low level) for LOD and LOQ: This method was determined over the concentration range of 25-125 ppm for methanol and 50-250 ppm for ethyl acetate. Two replicates were performed at each level. Correlation coefficient $\left(\mathrm{R}^{2}\right)$, steyx, slope, LOD and LOQ were calculated from these linearity data and are shown in Table-4.

Linearity: The linearity solutions were prepared for each organic volatile impurity over the range of LOQ to $750 \mathrm{ppm}$ for methanol, LOQ to $1500 \mathrm{ppm}$ for ethyl acetate. For each level 

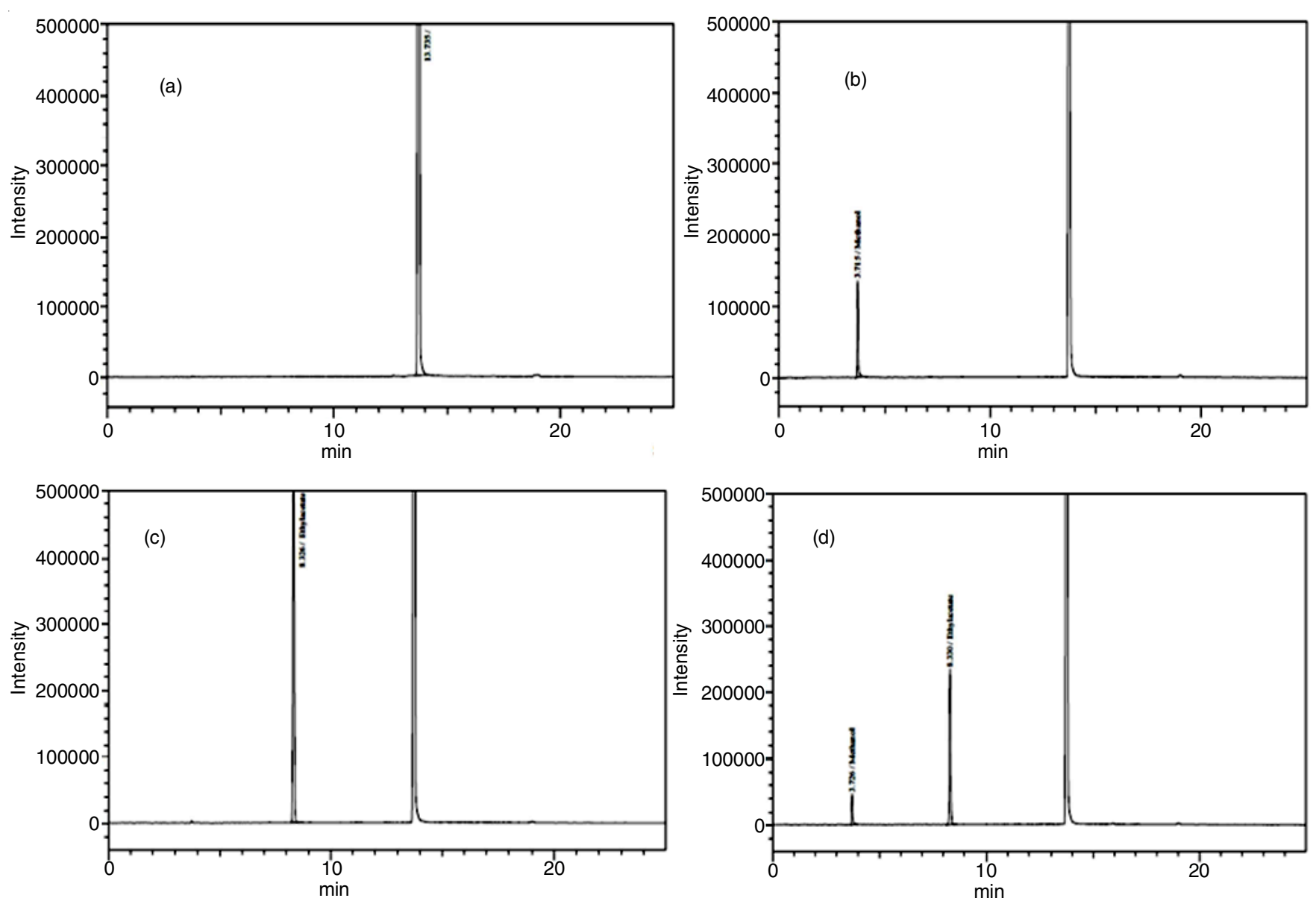

Fig. 2. Specificity for (a) blank (b) methanol (c) ethyl acetate and (d) spiked

\begin{tabular}{lc|ll}
\hline & \multicolumn{2}{c}{ TABLE-4 } \\
\multicolumn{4}{c}{$\begin{array}{c}\text { LINEARITY (LOW LEVEL) DATA FOR } \\
\text { METHANOL AND ETHYL ACETATE }\end{array}$} \\
\hline \multicolumn{3}{c}{ Methanol } & \multicolumn{2}{c}{ Ethyl acetate } \\
\hline $\mathrm{r}^{2}$ & 0.997 & $\mathrm{r}^{2}$ & 0.9996 \\
STEYX & 1085 & STEYX & 2332 \\
Slope & 308 & Slope & 870 \\
LOD $(\mathrm{ppm})$ & 12 & LOD $(\mathrm{ppm})$ & 9 \\
LOQ $(\mathrm{ppm})$ & 35 & LOQ $(\mathrm{ppm})$ & 27 \\
\hline
\end{tabular}

two replicates were performed. To draw the linearity graph between concentration and area of two replicates of organic volatile impurities. Finally the obtained correlation coefficient $\left(\mathrm{r}^{2}\right)$ was not less than 0.999 for two organic volatile impurities. The linearity data is presented in Table-5.

Limit of detection (LOD) and limit of quantitation (LOQ): The LOQ and LOD of organic volatile impurities in

TABLE-5

LINEARITY DATA FOR METHANOL AND ETHYL ACETATE

\begin{tabular}{cc|cc}
\hline \multicolumn{2}{c|}{ Methanol } & \multicolumn{2}{c}{ Ethyl acetate } \\
\hline Conc. $(\mathrm{ppm})$ & Average area & Conc. (ppm) & Average area \\
\hline $35(\mathrm{LOQ})$ & 9627 & 27 (LOQ) & 16096 \\
250 & 59150 & 500 & 457073 \\
375 & 87243 & 750 & 670066 \\
500 & 115520 & 1000 & 878032 \\
625 & 150270 & 1250 & 1136705 \\
750 & 176101 & 1500 & 1302636 \\
$\mathrm{r}^{2}$ & 1.000 & $\mathrm{r}^{2}$ & 0.999 \\
\hline
\end{tabular}

sertraline $\mathrm{HCl}$ were determined through slope method. The data and chromatograms of LOD and LOQ are presented in Table-6 and Fig. 3, respectively.

\begin{tabular}{ccccc}
\multicolumn{5}{c}{ TABLE-6 } \\
\multicolumn{5}{c}{ LOD AND LOQ DATA FOR } \\
METHANOL AND ETHYL ACETATE \\
\hline \multirow{2}{*}{ Name } & $\begin{array}{c}\text { LOQ } \\
(\mathrm{ppm})\end{array}$ & $\begin{array}{c}\text { LOD } \\
(\mathrm{ppm})\end{array}$ & $\begin{array}{c}\text { Area of } \\
\text { LOD }\end{array}$ & $\begin{array}{c}\text { Area of } \\
\text { LOQ }\end{array}$ \\
\hline Methanol & 35 & 12 & 5652 & 9627 \\
Ethyl acetate & 27 & 9 & 3966 & 16096 \\
\hline
\end{tabular}

Accuracy: A known amount of methanol and ethyl acetate standard solutions were spiked to sertraline $\mathrm{HCl}$ sample at three different concentrations (50,100,150 and LOQ) and injected in triplicate. The percentage recovery of organic volatile impurities were obtained 90 to $110 \%$ and \% RSD is less than 10 (Table$7)$.

System precision at LOQ: The system precision of this GC-HS method is expressed in term of \% RSD of data. System precision at LOQ concentration has been demonstrated by inject the six replicates of standard solutions. The obtained \% RSD was less than $10 \%$ (Table-8).

Robustness: To determine the robustness of present GC-HS method, \% RSD was checked for, to change the any two method parameters from the initial conditions. That parameters are column flow $\pm 0.2 \mathrm{~mL} / \mathrm{min}$ and vial condition temperature \pm $5{ }^{\circ} \mathrm{C}$. Finally in two changed method parameters, the \%RSD 

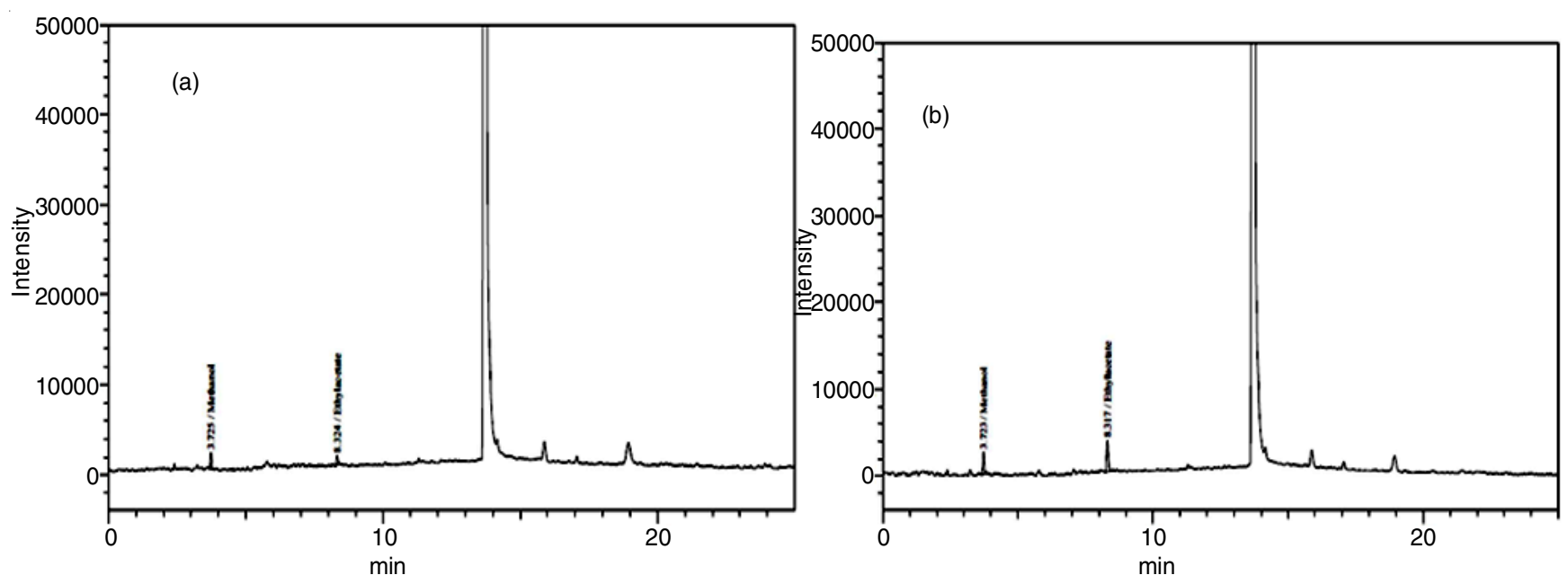

Fig. 3. LOD and LOQ graph for (a) methanol and (b) ethyl acetate

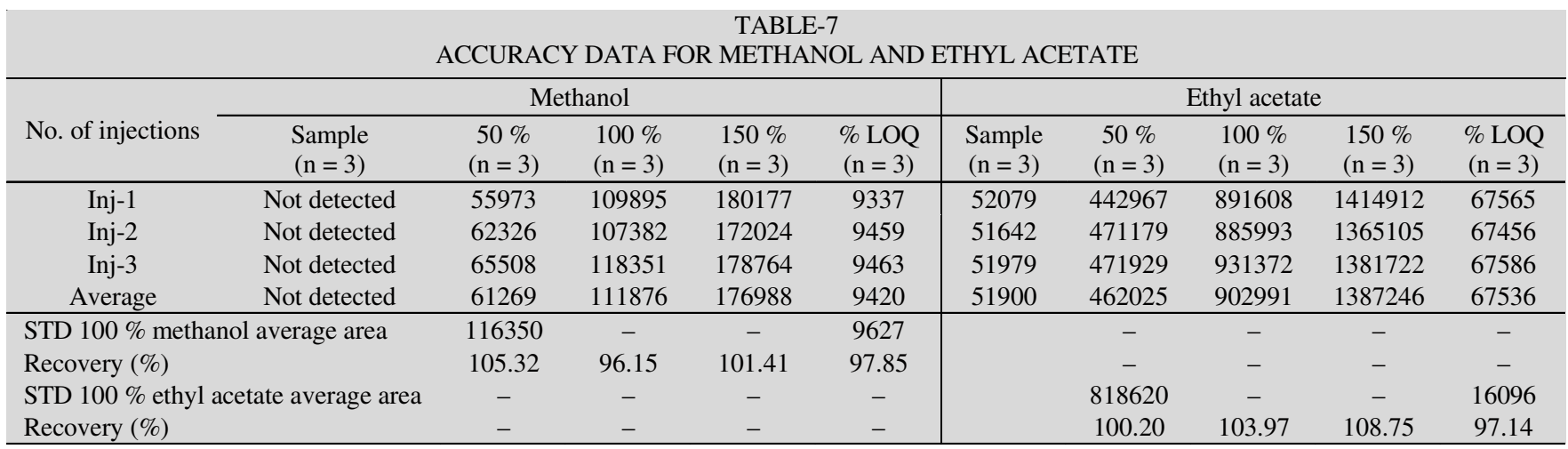

\begin{tabular}{ccc|cc}
\multicolumn{5}{c}{ TABLE-8 } \\
\multicolumn{5}{c}{$\begin{array}{c}\text { SYSTEM PRECISION DATA AT LOQ FOR } \\
\text { METHANOL AND ETHYL ACETATE }\end{array}$} \\
\hline No. of & \multicolumn{2}{c}{ Methanol } & \multicolumn{2}{c}{ Ethyl acetate } \\
\cline { 2 - 5 } injections & RT & Area & RT & Area \\
\hline 1 & 3.722 & 9551 & 8.320 & 15931 \\
2 & 3.723 & 9644 & 8.316 & 16015 \\
3 & 3.724 & 9687 & 8.318 & 16103 \\
4 & 3.723 & 9557 & 8.317 & 16091 \\
5 & 3.723 & 9645 & 8.317 & 16362 \\
6 & 3.722 & 9677 & 8.316 & 16073 \\
Mean & 3.72 & 9627 & 8.32 & 16096 \\
STDV & 0.00 & 59 & 0.002 & 145 \\
RSD (\%) & 0.02 & 0.61 & 0.02 & 0.90 \\
\hline
\end{tabular}

was less than $10 \%$ for each organic volatile impurity (Tables 9 and 10).
Ruggedness: Ruggedness has been established by separate six analyses of single batch of sample prepared by two different analysts on different days. Overall RSD of residual solvents were found out to be less than $10 \%$ (Table-11).

Tablet analysis: The prepared tablet solution $(250 \mathrm{mg} / \mathrm{mL})$ was injected and run into GC-HS. The methanol and ethyl acetate contents in sertraline $\mathrm{HCl}$ tablets were found within the limits. Results are summarized in Table-12. Typical chromatogram of sertraline $\mathrm{HCl}$ tablet is shown in Fig. 4.

\section{Conclusion}

The developed GC-HS method is simple, sensitive, accurate and highly precise for the determination and quantification of methanol and ethyl acetate in sertraline $\mathrm{HCl}$ and its pharmaceutical dosage forms. This GC-HS method was proposed for the quality control sertraline $\mathrm{HCl}$ in relation to the organic volatile

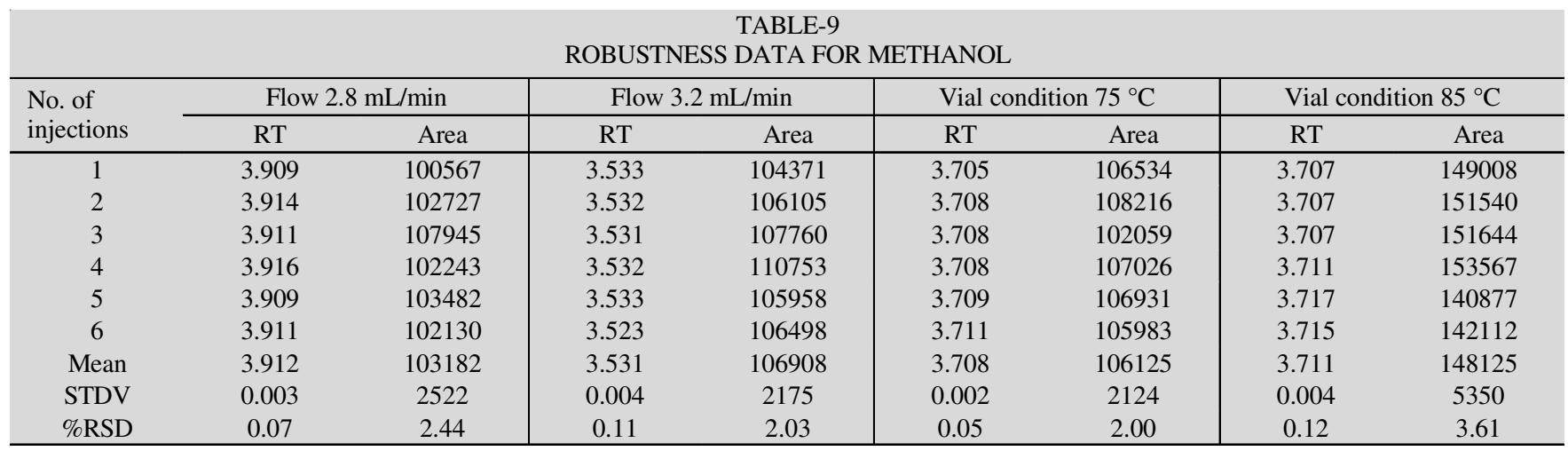




\begin{tabular}{|c|c|c|c|c|c|c|c|c|}
\hline \multicolumn{9}{|c|}{$\begin{array}{c}\text { TABLE-10 } \\
\text { ROBUSTNESS DATA FOR ETHYL ACETATE }\end{array}$} \\
\hline \multirow{2}{*}{$\begin{array}{l}\text { No. of } \\
\text { injections }\end{array}$} & \multicolumn{2}{|c|}{ Flow $2.8 \mathrm{~mL} / \mathrm{min}$} & \multicolumn{2}{|c|}{ Flow $3.2 \mathrm{~mL} / \mathrm{min}$} & \multicolumn{2}{|c|}{ Vial condition $75^{\circ} \mathrm{C}$} & \multicolumn{2}{|c|}{ Vial condition $85^{\circ} \mathrm{C}$} \\
\hline & RT & Area & RT & Area & RT & Area & RT & Area \\
\hline 1 & 8.523 & 819258 & 8.107 & 858241 & 8.296 & 815901 & 8.304 & 1106807 \\
\hline 2 & 8.530 & 916458 & 8.107 & 938295 & 8.300 & 801840 & 8.304 & 1168373 \\
\hline 3 & 8.526 & 841955 & 8.106 & 993931 & 8.302 & 806949 & 8.305 & 1174338 \\
\hline 4 & 8.529 & 843132 & 8.107 & 928268 & 8.300 & 832997 & 8.311 & 1178120 \\
\hline 5 & 8.526 & 876036 & 8.106 & 922987 & 8.303 & 832113 & 8.314 & 1063748 \\
\hline 6 & 8.529 & 851868 & 8.101 & 931002 & 8.304 & 748047 & 8.314 & 1098480 \\
\hline Mean & 8.527 & 858118 & 8.106 & 928787 & 8.301 & 806308 & 8.309 & 1131644 \\
\hline STDV & 0.003 & 33940 & 0.002 & 43243 & 0.003 & 31257 & 0.005 & 48287 \\
\hline $\operatorname{RSD}(\%)$ & 0.03 & 3.96 & 0.03 & 4.66 & 0.03 & 3.88 & 0.06 & 4.27 \\
\hline
\end{tabular}

TABLE-11

RUGGEDNESS DATA FOR METHANOL AND ETHYL ACETATE

\begin{tabular}{|c|c|c|c|c|c|c|c|c|}
\hline \multirow{3}{*}{ Days and analysts } & \multicolumn{4}{|c|}{ Methanol } & \multicolumn{4}{|c|}{ Ethyl acetate } \\
\hline & \multicolumn{2}{|c|}{ Mean \pm SD $(n=6)$} & \multicolumn{2}{|c|}{$\% \operatorname{RSD}(\mathrm{n}=6)$} & \multicolumn{2}{|c|}{ Mean \pm SD $(n=6)$} & \multicolumn{2}{|c|}{$\% \operatorname{RSD}(\mathrm{n}=6)$} \\
\hline & RT & Area & RT & Area & RT & Area & RT & Area \\
\hline Day-1 (Analyst-1) & $3.732 \pm 0.001$ & $113814 \pm 2405$ & 0.03 & 2.11 & $8.331 \pm 0.002$ & $810161 \pm 10401$ & 0.03 & 1.28 \\
\hline Day-1 (Analyst-2) & $3.725 \pm 0.003$ & $114885 \pm 2889$ & 0.07 & 2.52 & $8.324 \pm 0.005$ & $854453 \pm 18051$ & 0.06 & 2.11 \\
\hline Day-2 (Analyst-1) & $3.721 \pm 0.003$ & $116405 \pm 2256$ & 0.09 & 1.94 & $8.317 \pm 0.006$ & $809570 \pm 4535$ & 0.06 & 0.56 \\
\hline \multirow{3}{*}{ Day-2 (Analyst-2) } & $3.731 \pm 0.001$ & $114109 \pm 3125$ & 0.02 & 2.74 & $8.320 \pm 0.001$ & $818964 \pm 16448$ & 0.01 & 2.01 \\
\hline & \multicolumn{2}{|c|}{ Mean $\pm \operatorname{SD}(n=12)$} & \multicolumn{2}{|c|}{$\% \operatorname{RSD}(\mathrm{n}=12)$} & \multicolumn{2}{|c|}{ Mean $\pm \operatorname{SD}(n=12)$} & \multicolumn{2}{|c|}{$\% \operatorname{RSD}(\mathrm{n}=12)$} \\
\hline & RT & Area & RT & Area & RT & Area & RT & Area \\
\hline Day-1 (Analyst-1\&2) & $3.729 \pm 0.004$ & $114350 \pm 2596$ & 0.11 & 2.27 & $8.327 \pm 0.005$ & $832307 \pm 27061$ & 0.06 & 3.25 \\
\hline Day-2 (Analyst-1\&2) & $3.721 \pm 0.002$ & $115257 \pm 2862$ & 0.06 & 2.48 & $8.318 \pm 0.004$ & $814267 \pm 12505$ & 0.05 & 1.54 \\
\hline Analyst-1 (Day1\&2) & $3.726 \pm 0.006$ & $115110 \pm 2603$ & 0.17 & 2.26 & $8.324 \pm 0.008$ & $809865 \pm 7656$ & 0.10 & 0.95 \\
\hline Analyst-2 (Day1\&2) & $3.723 \pm 0.003$ & $114597 \pm 2898$ & 0.07 & 2.53 & $8.322 \pm 0.004$ & $836709 \pm 24790$ & 0.02 & 2.96 \\
\hline
\end{tabular}

TABLE-12

METHANOL AND ETHYL ACETATE CONTENT IN TABLET ANALYSIS

\begin{tabular}{cccc}
\hline Name of drug & $\begin{array}{c}\text { Label claim } \\
(\mathrm{mg})\end{array}$ & $\begin{array}{c}\text { Methanol } \\
(\mathrm{ppm})\end{array}$ & $\begin{array}{c}\text { Ethyl acetate } \\
(\mathrm{ppm})\end{array}$ \\
\hline Sertraline $\mathrm{HCl}$ & 500 & Not detected & 75 \\
\hline
\end{tabular}

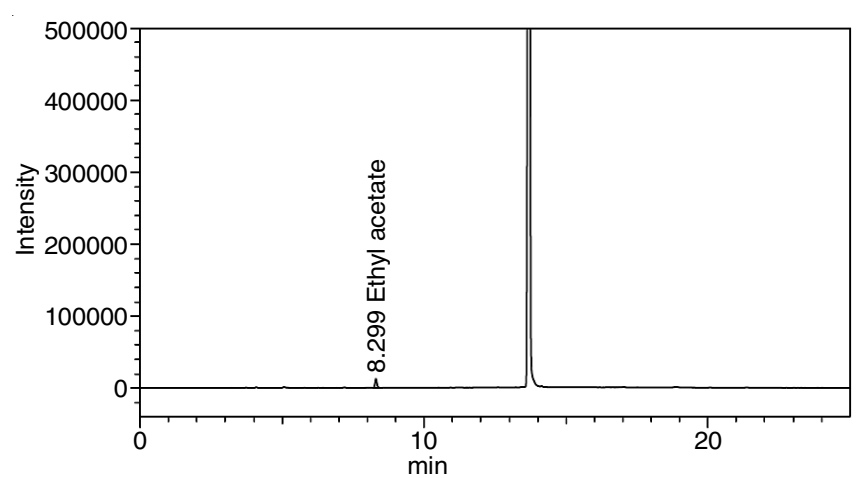

Fig. 4. Chromatogram for sertraline $\mathrm{HCl}$ tablet

methanol and ethyl acetate contents and meets the validation requirements. The good results were found within the range as per ICH guidelines. Three randomly selected batches of each drug substance were analyzed under validated method conditions and the concentrations of residual methanol and ethyl acetate were much lower than their maximum limits.

\section{REFERENCES}

1. M.M. Khater, Y.M. Issa, H.B. Hassib and S.H. Mohammed, J. Adv. Res., 6, 459 (2015);

https://doi.org/10.1016/j.jare.2014.11.005.

2. F. Bonadio, P. Margot, O. Delémont and P. Esseiva, Forensic Sci. Int., 187, 73 (2009);

https://doi.org/10.1016/j.forsciint.2009.03.004.

3. J. Li, S. Shao, M. Solorzano, G.J. Allmaier and P.T. Kurtulik, J. Chromatogr. A, 1216, 3328 (2009);

https://doi.org/10.1016/j.chroma.2009.02.029.

4. R. Barro, J. Regueiro, M. Llompart and C. Garcia-Jares, J. Chromatogr. A, 1216, 540 (2009);

https://doi.org/10.1016/j.chroma.2008.10.117.

5. V. Pinnel, P. Rosseels and J. Vandegans, J. High Resolut. Chromatogr., 18, 776 (1995); https://doi.org/10.1002/jhrc.1240181212.

6. ICH Harmonized Tripartite Guidelines for Residual Solvents. Step 4, 17 July (1997).

7. K. Fliszar, J.M. Wiggins, C.M. Pignoli, G.P. Martin and Z. Li, J. Chromatogr. A, 1027, 83 (2004); https://doi.org/10.1016/j.chroma.2003.08.086.

8. ICH, Guidelines Q2B Validation of Analytical Procedures Methodology, In: Proceedings of I.C.H. Public Meeting, Rockville, USA, pp. 1-10 (1996). 